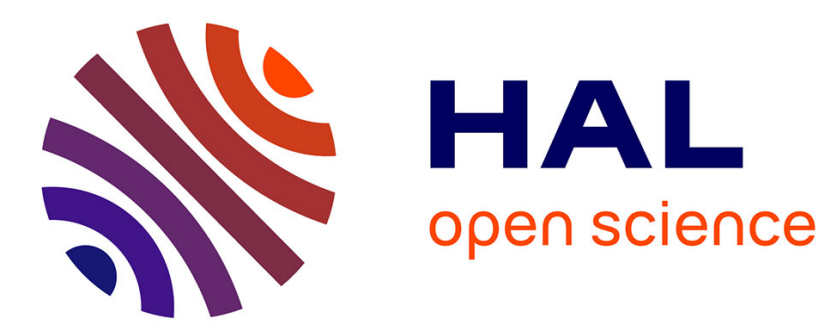

\title{
First information about two Asian Pear collections in France
}

\author{
Bernard Thibault, A. Masseron, André Belouin, E. Dalle
}

\section{To cite this version:}

Bernard Thibault, A. Masseron, André Belouin, E. Dalle. First information about two Asian Pear collections in France. Acta Horticulturae, 1989, 256, pp.23-34. hal-01600926

\section{HAL Id: hal-01600926 \\ https://hal.science/hal-01600926}

Submitted on 2 Jun 2020

HAL is a multi-disciplinary open access archive for the deposit and dissemination of scientific research documents, whether they are published or not. The documents may come from teaching and research institutions in France or abroad, or from public or private research centers.
L'archive ouverte pluridisciplinaire HAL, est destinée au dépôt et à la diffusion de documents scientifiques de niveau recherche, publiés ou non, émanant des établissements d'enseignement et de recherche français ou étrangers, des laboratoires publics ou privés.

\section{다(1)(2)}

Distributed under a Creative Commons Attribution - ShareAlike| 4.0 International 
FIRST INFORMATION ABOUT TWO ASIAN PEAR COLLECTIONS IN FRANCE

B. Thibault , A. Masseron ${ }^{* *}$, A. Belouin ${ }^{*}$, E. Dalle ${ }^{* *}$

* Institut National de la Recherche Agronomique, INRA

Station d'Amélioration des Espèces fruitières et ornementales

Beaucouzé, 49000 Angers (France)

** Centre Technique Interprofessionnel des Fruits et Légumes, CTIFL

Centre de Lanxade

Prigonrieux, 24130 La Force (France)

\section{Abstract}

A collection of 23 Asian pear varieties was established during the $83 / 84$ winter in two sites in France: Angers and Bergerac. The trees had been budded on seedlings of Pyrus serotina and Pyrus calleryana.

The pedo-climatic situations, the first results on the behaviour of the trees, vigour and first bearing are provided.

Observations carried on blooming period, thinning, picking date, number and weight of fruits. A description of the aspect and quality is given as storage capacity.

Introduction

Fruit tree research station in Angers introduced in 1981 from Fruit tree research station Yatabe, Ibaraki in Japan 18 Japanese pear varieties. In August 1982 they were budded on seedlings of Pyrus serotina and Pyrus calleryana (D.6 selection). Four Chinese varieties and the Japanese pear 'Okusankichi' were added. (table 1).

During the winter $1983 / 1984$ one tree of each combination was planted in Angers (Loire valley) and in Bergerac (South-West of France) on the experimental farm of CTIFL. The characteristics of the soil and climate are shown in table 2. Irrigation is established on both sites.

Results

Generally speaking the affinity was good to very good and the budding was successful on the two types of rootstocks. It was possible to establisk, in nursery, a classification according to the girth of the trunk and the height of the maiden trees. (table 3 ).

It was possible to note:

- for girth of the trunk : 13 varieties were classed above $56 \mathrm{~mm}$ with Pyrus serotina and 10 with Pyrus calleryana. On the contrary 10 were classed below $56 \mathrm{~mm}$ with Pyrus calzeryana and 6 only with Pyrus serotina. - for the height of maiden trees : 10 varieties were above $1.50 \mathrm{~m}$ with Pyrus serotina and 7 with Pyrus calleryana. On the opposite side 12 varieties were classed below $1.50 \mathrm{~m}$ with Pyrus calleryana and 10 with Pyrus serotina. 
It seems, on the whole, that seedlings of Pyrus serotina gave a better vigour, in nursery, than seedlings of Pyrus calleryana.

In Angers the trees were planted obliquely (flag form on treillis). In Bergerac they were planted in free spindle axis.

First flowers came very quickly, as soon as 1985 for the majority of the varieties. The flowering time in 1985, 1986 and 1987 was very late; so the number of flowering days was limited. In 1988 this number of days was larger : trom March 21 st until April 16th. The table 4 gives the order of flowering time in Angers and Bergerac for 1988. Some varieties as 'Nijisseiki' 'Shinko' - 'Suisei' had a long period of flowering. In Angers twelve varieties bloomed before 'Passe Crassane'. Ten bloomed at the same period and only one bloomed after. In Bergerac eight varieties bloomed before 'Williams', ten bloomed at the same period. Only 'Kimizuka Wase' - 'Choju' - 'Okusankichi' and 'Kumoi' bloomed after.

After three years of growing the vigour which was better on Pyrus serotina in the nursery was a little better on Pyrus calleryana in Angers but this is not so clear in Bergerac. In Angers the range was:

Three varieties were weak : 'Hakko' - 'Kikusui' - 'Yakumo' Seven were of medium vigour : 'Hayatama' - 'Hosui' - 'Kimizuka Wase' 'Kumoi' - 'Niitaka' - 'Shinsui' - 'Suisei'.

Three of medium to strong vigour : 'Choju' - 'Chojuro' - 'Tama'. Five of strong vigour : 'Kosui' - 'Nijisseiki' - 'Ping Guo Li' - 'Shinseiki' 'Xue Hua Li'.

Three of very strong vigour : 'Imamura Aki' - 'Jing Bai Li' - 'Ya Li'.

In Bergerac the range was approximately the same except 'Hosui' and 'Suisei' which were stronger and 'Choju' and 'Imamura Aki' which were weaker.

It was difficult to class the variety 'Shinko' which was of medium vigour on Pyrus serotina and much more vigourous on Pyrus calleryana.

Table 5 shows an example of the progression of the production in Angers for four important varieties. Production on Pyrus calzeryana was generally greater than on Pyrus serotina and this is true for the two sites.

Classes of the amount of production until 1987 included, are shown in table 6 for Angers. The figures for Bergerac were approximately the same. Extremes were in Angers from $4.8 \mathrm{~kg}$ ('Hakko') to $37.0 \mathrm{~kg}$ ('Imamura Aki') for trees on Pyrus serotina and from $4.3 \mathrm{~kg}$ ('Yakumo') to $52.2 \mathrm{~kg}$ ('Imamura Aki') for trees on Pyrus calleryana.

In Bergerac they were from $5.6 \mathrm{~kg}$ ('Hakko') to $42.0 \mathrm{~kg}$ ('Xue Hua Li') for trees on Pyrus serotina and from $3.4 \mathrm{~kg}$ ('Jing Bai Li') to $47.0 \mathrm{~kg}$ ('Shinseiki') for trees on Pyrus calleryana.

It must be noted that Chinese varieties bear fruit one year later than Japanese one. 
Picking time (table 7) ranked from beginning of August (6th in Bergerac, 10 th in Angers) to mid of October, the earliest being 'Hayatama' and the latest 'Imamura $\mathrm{Aki}$ ' and 'Okusankichi'. It is difficult to g ve a precise date, for the maturity on the tree is often spread.

The mean weight of the fruits is very variable according to picking time and mainly according to the intensity of thinning. It is possible, also, that the temperatures influence on this characteristic; so, it could be greater in warmer conditions so long as water is provided enough.

In Angers two varieties had very big fruits: 'Imamura Aki' and 'Xue Hua Li' (about $300 \mathrm{~g}$ ).

- three had big fruits : 'Chojuro' - 'Niitaka' - 'Ping Guc Li' (about $180 \mathrm{~g}$ ). - seven varieties had medium fruits : 'Hosui' - 'Kikusui' - 'Kimizuka Wase' 'Kosui' - 'Kumoi' - 'Shinko' - 'Ya Li' (about $150 \mathrm{~g}$ ).

- seven had small fruits : 'Choju' - 'Hakko' - 'Hayatama' - 'Nijisseiki' 'Shinseiki' - 'Suisei' and 'Tama' (about $125 \mathrm{~g}$ ).

- three had very small fruits : 'Jing Bai Li' - 'Shinsui' - 'Yakumo' (about $100 \mathrm{~g}$ ).

In Bergerac, mean weight of fruits was generally greater, the smallest : 'Jing Bai Li' - 'Hayatama' and 'Kimizuka Wase' weighing about $120 \mathrm{~g}$.

It is possible that the thinning had been more severe in Bergerac. Thinning is a very important work for Asian pears. For five principal varieties, the evolution of flower buds all along the year 1987 in Angers is given in table 8 .

Intensity of thinning can be measured by the number of clusters remaining after this operation (May and beginning of June). Percentage of removed clusters (col. 3) varies between 40 to $50 \%$. Number of removed fruits (col. 4) varies between 200 and 400 . Generally only one fruit by clusters stayed at the picking time. However for 'Chojuro' on Pyrus serotina one can find out a deficiency in the thinning leading to 1.73 fruits by cluster and an average weight of $115 \mathrm{~g}$. In order to tend towards a commercial size it is important to keep only one fruit by cluster.

Quantity of flower buds initiated during the 1987 summer varies from 170 to 694. It is 'Chojuro' which formed the greater number as well on Pyrus serotina as Pyrus calleryana.

Winter pruning leads already to a first thinning and the percentage of flower buds remaining after pruning varies from $23 \%$ to $39 \%$ for 'Chojuro' 'Hosui' and 'Kosui' to 52 to $91 \%$ for 'Choju' and 'Nijisseiki', two spur type varieties on which pruning is less heavy. This is confirmed by the percentage of flower buds located on one year old wood. It is from 30 to $69 \%$ on the three first varieties and only from 7 to $14 \%$ on the two last ones. 'Kikusui' and 'Shinko' are also of spur type. On the other hand 'Hosui' 'Kosui' and 'Shinsui' are lateral types.

After four years of growth it is possible to draw up some characteristics useful for the management of the trees. 
'Choju' : Thick and rigid one year old shoots bearing some ílowers. Good balance between growth and fruiting habit. Many bourses present flowers for the next year. Good reaction to shortening.

'Chojuro' : Rather good branching. Good balance. Good reaction to shortening of lateral shoots. Flowers on bourses and on annual wood. Long shoots.

'Hayatama' : Rather good branching. Good reaction to shortening of lateral shoots but few flowers on bourses. Flowers on annual wood but only at the top.

'Hcsui' : Some flowers on one year old shoots. Some flowers on bourses

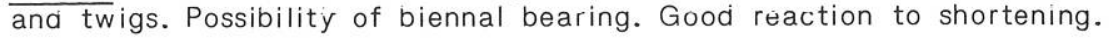

'Kimizuka Wase' : Few flowers on one year old shoots and on bourses. Tendency to be bare at the bottom of the tree. Flowers on darcis.

'Kosui' : Long rigid and brittle shoots. Flcwers mainly on dards and on annual wood. Spur can't be used for a long period.

'Kumoi' : Flowers on one year old shoots but only at the top. New shoots only by cutting back. Bourses without flowers. Rough bark.

'Nijisseiki' : Flowers on one year old shoots and on bourses. Spurs are flowering and fruiting many years. Shoots are not numerous.

'Shinko': Good balance between one year old shoots and twigs. Good reaction to shortening. Some flowers on annuai shoots. Difficulty of renewal.

'Shinseiki' : Good baiance between spurs aná one year old shoots; only lateral shoots bear flowers. Good reaction to shortening.

'Shinsui' : Weak branching. Difficulty to regenerate new growth. No fiowers on bourses. Old bourses become dry. Few flowers on annual shoots. Flowers mainiy on two year old shoots.

Attractiveness of the fruit is certainly one of the main and newer characteristics for Nashi. Three russet varieties and one yeliow were judged very attractive : 'Chojuro' - 'Kosui' - 'Shinink' and 'Shinseiki'.

Six russet and two yellow varieties were judged attractive : 'Choju' 'Hosui' - 'Kumoi' - 'Niitaka' - 'Shinsui' - 'Suisei' - 'Hakko' and 'Nijissei$\mathrm{Ki}$ '. It is also possible to put in this class 'Xue Hua Li' which is of yellowgreen colour with russeting.

Other varieties were less attractive for different reasons : shape of the fruit ('Ping Guo Li' and 'Imamura Aki'). Heterogeneity of the coloration (as 'Hayatama' - 'Kikusui' - 'Kimizuka Wase' or 'Tama'). Size of the fruit (as 'Jing Bai Li' or 'Yakumo').

Characteristics of the flesh were very close from one to another. However it was possible to distinguish some of them for a more pronounced fiavoui : 'Chojuro' - 'Hosui' - 'Kosui', a better texture : 'Hosui' or a fairly good level for different characteristics : 'Choju' - 'Kumoi' - 'Nijisseiki' 'Shinseiki' - 'Shinko' - 'Tama'.

Cold storage was very short for early varieties mainly for 'Hayatama' which was subject to scald. 
'Kimizuka Wase' and 'Shinsui' had a cold storage uniii mid of December.

'Choju' - 'Hakko' - 'Hosui' - 'Kumoi' - 'Nijisseiki' anj 'Tama' can be stored until end of December.
'Kikusui' - 'Kosui' - 'Niitaka' - 'Shinko' and 'Shinseiki' until mid of january.

Chinese varieties more 'Chojuro' and 'Imamura $\mathrm{Aki}^{\prime}$ can be kept until February.

But the great advantage of Asian pears is that they can be picked ripe and eaten immediately. Brilliancy of the skin and quality ciecreased gradually.

\section{Susceptibility to pests and diseases.}

Except red mites no particular suscepitibiity was noted in this collection.

Some varieties artificially inoculated on shoots by E'rwinia amyZovora were susceptible but no natural infection was observed. Secondary biouming is also very rare.

Virus indexing was undertaken in Angers by J. Lemoine.

* Eleven clones were found virus free : 'Hakko' - 'Hayatama' - 'Jing Bai Li' 'Kimizuka Wase' - 'Kumoi' - 'Niitaka' - 'Ping Guo Li' - 'Shinseiki' -

'Shinsui' - 'Suisei' and 'Xue Hua Li'.

* Four had only Stem grooving : 'Choju' - 'Chojuro' - 'Hosui' and 'Ya Li'.

* Three had Stem grooving more Vein yellows : 'Imamura Aki' - 'Kikusui' 'Kosui'.

* One had Stem grooving more Rubbery wood : 'Yakumo'.

* Three had three viruses:

- Stem grooving - Vein yeliows - Rubbery wood: 'Shinko' and 'Tama'

- Stem grooving - Vein yellows - Necrotic spot : 'Nijisseiki'.

Stem grooving which is not very common on Pyrus communis can induce a bad affinity at the graft union. Necrotic spot is unknown on $P$. communis and detected only by $\mathrm{HN} 39$ indicator in greenhouse.

Thermotherapy is undertaken in Bergerac for some varieties.

Other susceptibilities must be noted:

- a general susceptibility to magnesium deficiency

- a susceptibility to leaf burning of 'Kosui' and 'Kimizuka Wase'.

- a generai attractivity for birds.

Temperatures during the winters 1985 - 1986 and 1987 were very severe as well in Angers as in Bergerac. However no cold damage was observed. 
In conclusion we can note the good adaptation of Asian pears to climatic conditions of Western part of France.

We will have to solve some problems as selection of good rootstocks possibly propagated by a vegetative way. The choose of varieties can put down into a double frame : colour and picking time; another point for choosing is also the repute on the international market.

Until now, if precocity is desired 'Hayatama' must be choosen but 'Kimizuka Wase' and 'Choju' seems to have also some interest. A littie iess precocious is 'Shinseiki' and it is the first yellow variety with a good cropping.

'Kosui' and 'Hosui' are more and more planted in Japan and New Zealand; so their place on the future market is sure.

The problem is different with 'Chojuro' and 'Nijisseiki'. These old varieties present some qualities but also some defects : mainly a coarse flesh for the first and susceptibility to Black spot for the second.

If a long stcrage is desired, 'Shinko' can be choosen in preference to 'Niitaka', 'Okusankichi' or 'Imamura Aki'.

An important point for the management of the orchard is the thinning. In order to obtain big and well shaped fruits this work is necessary and it is consuming time. In the same way picking must be made very carefully mainly for yellow varieties the skin of which is very susceptible to bruising and discoloration. Picking must be foreseen in at least two times.

Finally economical problems will be perhaps more important for this new fruit than technical ones. 


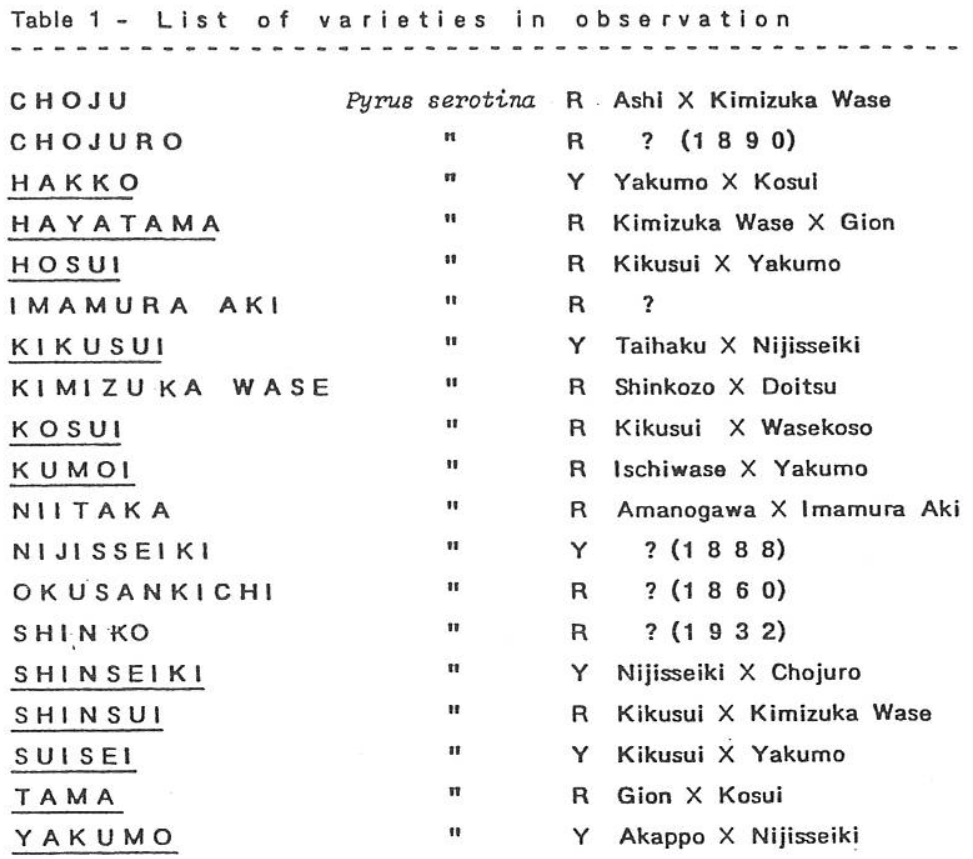

JING BAI LI Pyrus ussuriensis

PING GUO LI Pyrus serotina $X$ P. ussuriensis

$X U E$ HUA LI Pymus bretschneideri

Y A LI Pyms bretschneideri

Underlined varieties have $\mathrm{NIJISSEIKI}$ in their pedigree

$R=$ russet $\quad Y=y e 110 w$ 


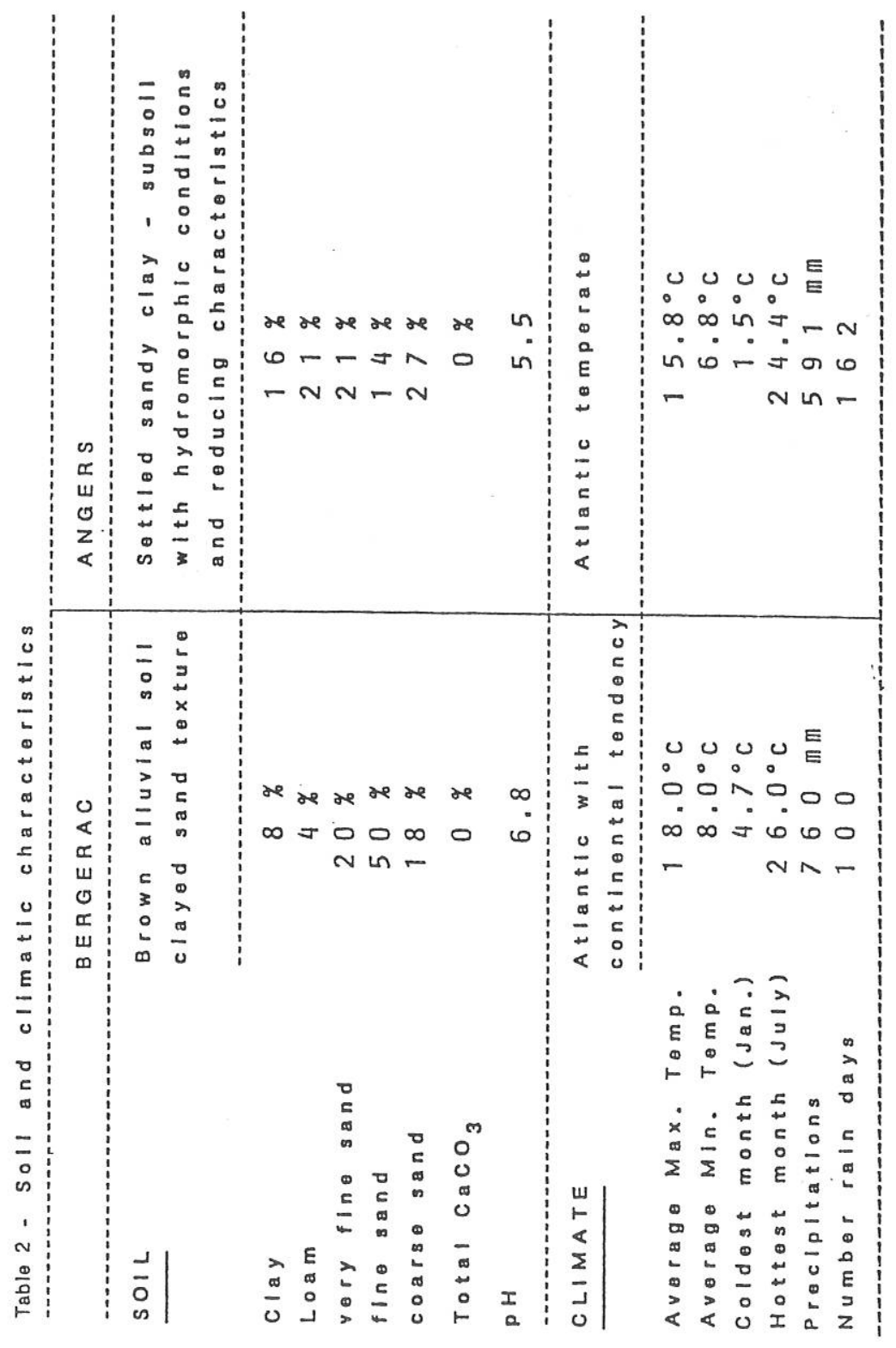




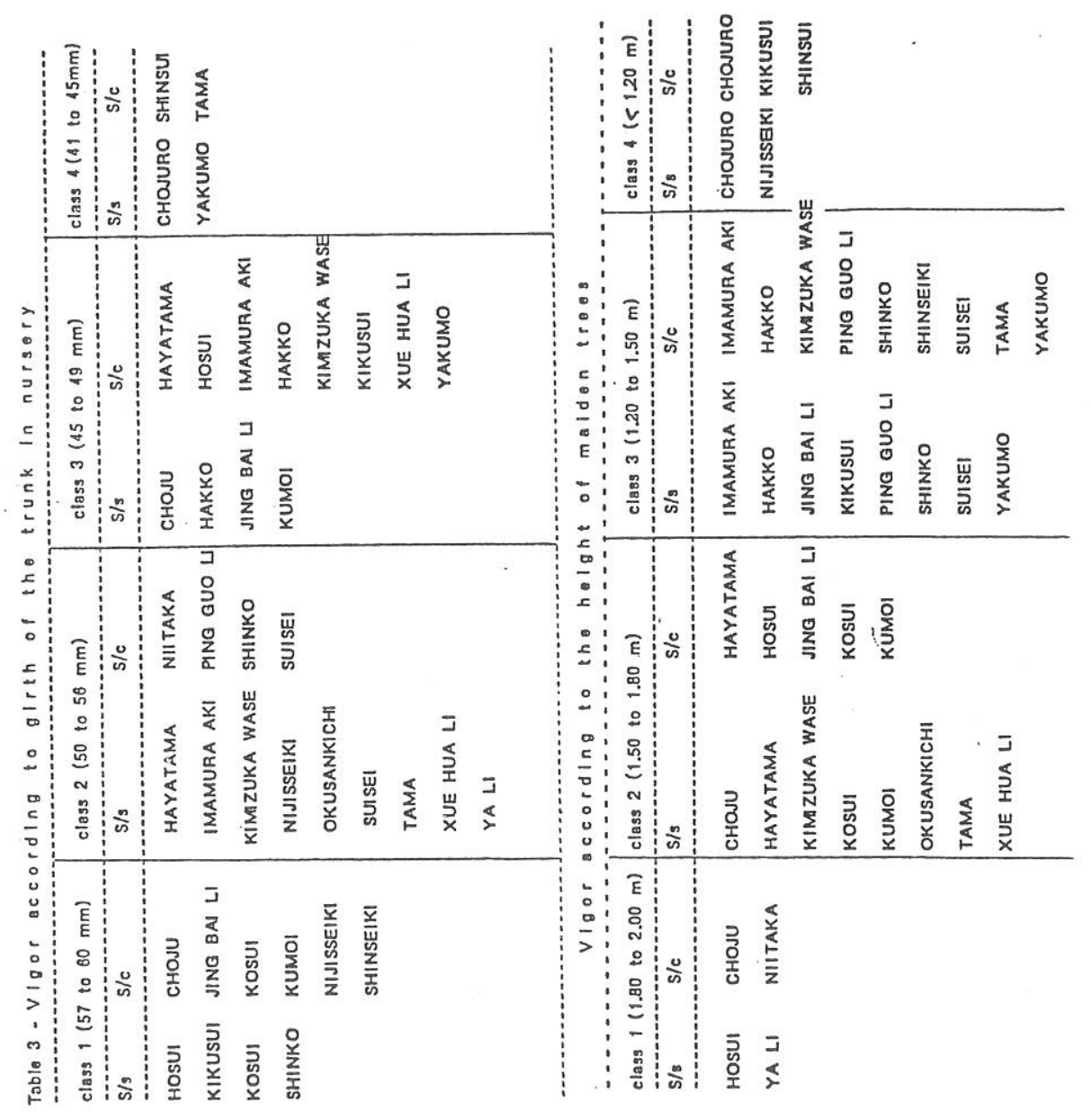


Table 4 - Flowering order in 1988

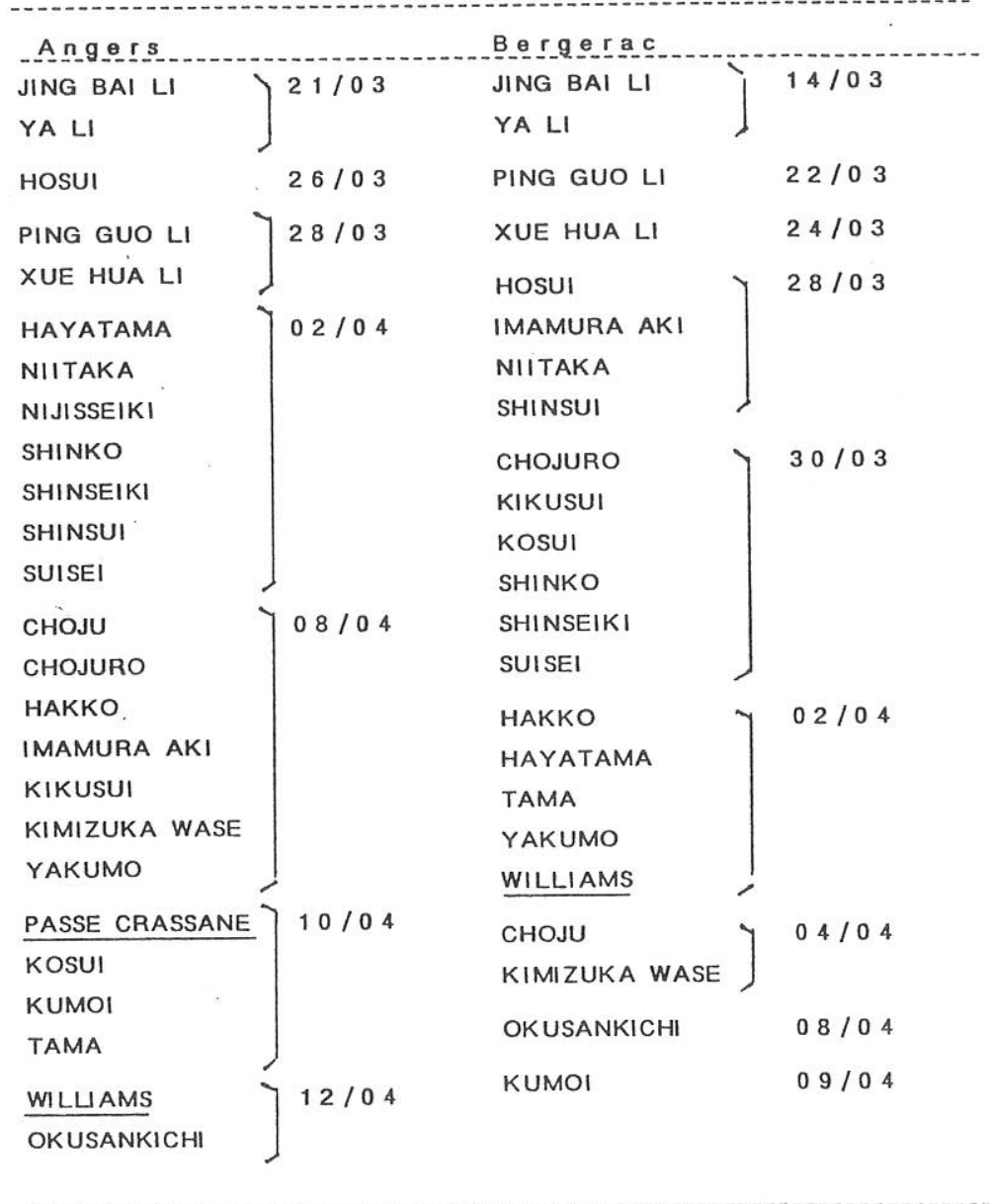


Table 5-Progression of the production (kg/tree) In Angers

\begin{tabular}{|c|c|c|c|c|c|c|}
\hline$A g O$ & Year & CHOJURO & HOSUI & KOSUI & NIJISSEIKI & Total \\
\hline $2 d$ & 1985 & 3.2 & 2.2 & $1 \cdot 8$ & 2.8 & 10.0 \\
\hline $3 \mathrm{rd}$ & 1986 & 5.4 & $2 \cdot 7$ & 5.8 & 8.0 & 21.9 \\
\hline \multirow[t]{2}{*}{$4 \mathrm{th}$} & 1987 & 15.5 & 11.4 & 15.6 & 16.7 & 59.2 \\
\hline & & $24 \cdot 1$ & 16.3 & 23.2 & 27.5 & $91 \cdot 1$ \\
\hline \multicolumn{7}{|c|}{2 - on P. calleryana } \\
\hline $\mathrm{Ag} \theta$ & Year & CHOJURO & HOSUI & KOS U I & NIJISSEIKI & Tot a I \\
\hline $2 d$ & 1985 & $4 \cdot 6$ & $3 \cdot 4$ & $2 \cdot 9$ & $4 \cdot 1$ & 15.0 \\
\hline $3 \mathrm{rd}$ & $\uparrow 986$ & 16.2 & $3 \cdot 5$ & 8.9 & $7 \cdot 3$ & 35.9 \\
\hline $4 \mathrm{th}$ & 1987 & 24.4 & 14.9 & 22.0 & 23.8 & 85.1 \\
\hline & · & 45.2 & $21 \cdot 8$ & 33.8 & 35.2 & 136.0 \\
\hline
\end{tabular}

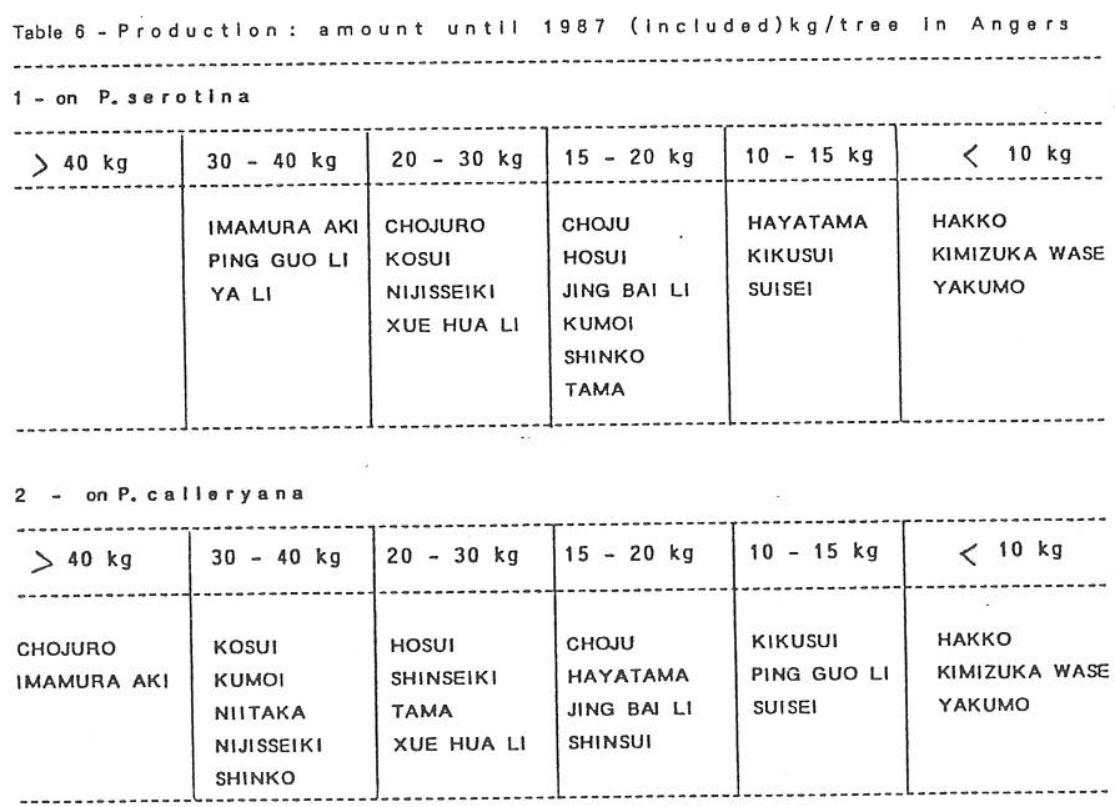


Table 7 - Picking time (ranked in each column)

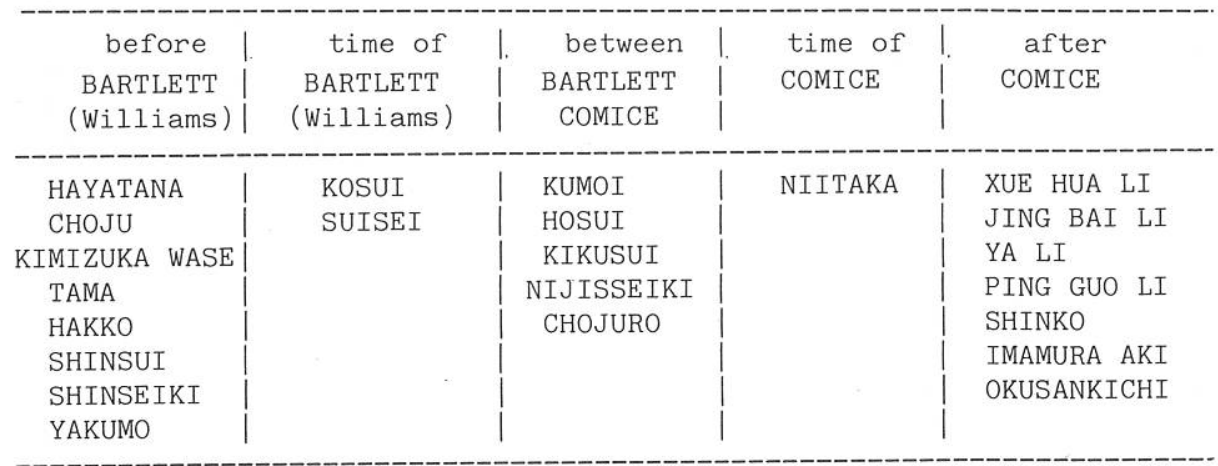

In Angers 'Bartlett' is generally picked about August 20 th and 'Comice' about September 20 th

Table 8 - Evolution of flower buds (F.B.) all along the $87 / 88$ season
in Angers

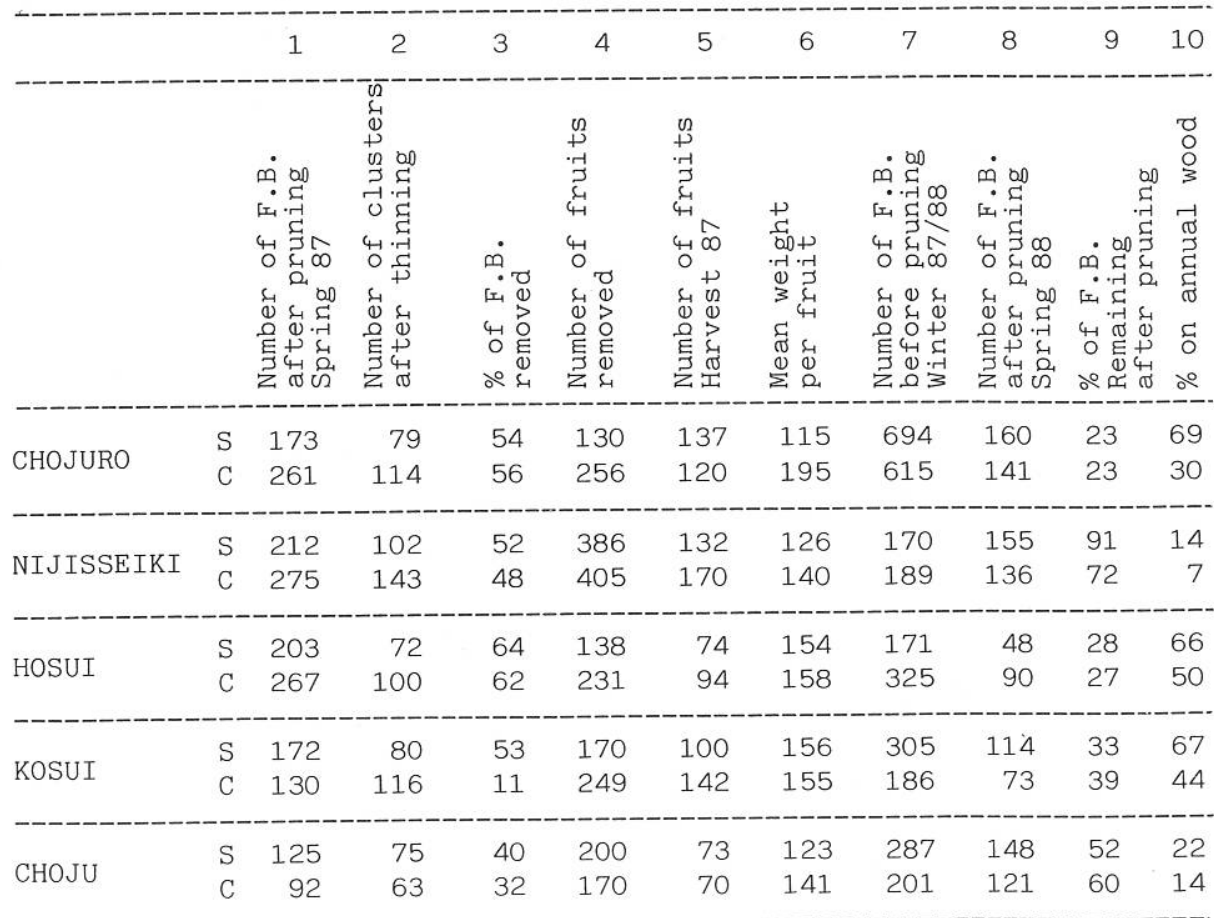

$\mathrm{S}=\mathrm{P}$. serotina

$c=P$. calleriana 